\title{
Adherence to the treatment of individuals with the HIV/tuberculosis co-infection: integrative review
}

\author{
Lis Neves ${ }^{1 *}$, Renata Reis ${ }^{2}$, Elucir Gir ${ }^{1}$, Patrícia Ribeiro ${ }^{1}$ \\ From $16^{\text {th }}$ International Symposium on HIV and Emerging Infectious Diseases \\ Marseille, France. 24-26 March 2010
}

\section{Background}

The study it deals with integrative review whose objective was to evaluate the available evidences in literature on the factors associate with adherence to the treatment of patients with the HIV/Tuberculosis (TB) co - infection.

\section{Methods}

Were collected articles published in the period of 2002 to 2008, through LILACS and MEDLINE databases, which contained questions related to the proposed objective; the articles had been categorized in accordance with the year of publication, periodic, local of the study and factors related to the adhesion. The final sample was composed for eight articles.

\section{Results}

Five studies were developed in Brazil and others in Peru, USA and France. The factors associates to the adherence to the treatment of co-infection HIV/TB were grouped into 3 categories:

1. Related to the individual and its style of life previous treatment of TB, distrust of stigma, chemical substance use, depression, social support;

2. Related to the illness and treatment - type of medicines regimen and complexity, collateral effect, difficulty of diagnosis of TB in patients with aids;

3. Related to the health services - operational problems to follow the treatment, the cost of drugs, training of the professionals, supervision of treatment (DOTS), doctor -patient relationship, distinct places for HIV and TB attendance.

* Correspondence: lisapneves@yahoo.com.br

1 são Paulo University - School Of Nursing De Ribeirão Preto , Ribeirão Preto, Brazil

\section{Discussion}

Adherence to treatment of the co - infection HIV/TB isn't a theme very explored in the cientific literature. Co - infection HIV/TB brings a strong impact on the epidemic behavior of both diseases and is responsible for increased rates of mortality, making it a challenge to public health. The patient compliance issues is influenced by multiple factors; the health professionals should be trained and be alert for the presence of life's situations that can increased his vulnerability and cause disruptions in the adherence to the treatment.

\section{Author details}

1 são Paulo University - School Of Nursing De Ribeirão Preto , Ribeirão Preto, Brazil. ªlagoas University, Maceió, Brazil.

Published: 11 May 2010

doi:10.1186/1742-4690-7-S1-P188

Cite this article as: Neves et al:: Adherence to the treatment of individuals with the HIV/tuberculosis co-infection: integrative review. Retrovirology 2010 7(Suppl 1):P188.

Submit your next manuscript to BioMed Central and take full advantage of:

- Convenient online submission

- Thorough peer review

- No space constraints or color figure charges

- Immediate publication on acceptance

- Inclusion in PubMed, CAS, Scopus and Google Scholar

- Research which is freely available for redistribution

Submit your manuscript at www.biomedcentral.com/submit
C Biomed Central 